\author{
Asian Journal of \\ Medical and Biological Research \\ ISSN 2411-4472 (Print) 2412-5571 (Online) \\ www.ebupress.com/journal/ajmbr
}

\title{
Article \\ Determination of appropriate level of fat in milk for the production of good quality dahi
}

\author{
Morsheda Yesmin ${ }^{1}$, Md. Rezaul Hai Rakib ${ }^{2 *}$, Al Amin Hossain ${ }^{3}$, Akhi Khan ${ }^{3}$ and Md. Nurul Islam ${ }^{4}$ \\ ${ }^{1}$ Scientific Officer, Sheep Project, Bangladesh Livestock Research Institute, Savar, Dhaka-1341, Bangladesh \\ ${ }^{2}$ Scientific Officer, Goat and Sheep production Research Division, Bangladesh Livestock Research Institute, \\ Savar, Dhaka-1341, Bangladesh \\ ${ }^{3}$ Scientific Officer, Department of Livestock Services, Farmgate, Dhaka, Bangladesh \\ ${ }^{4}$ Department of Dairy Science, Bangladesh Agricultural University, Mymensingh-2202, Bangladesh
}

*Corresponding author: Md. Rezaul Hai Rakib, Scientific Officer, Goat and Sheep production Research Division, Bangladesh Livestock Research Institute, Savar, Dhaka-1341, Bangladesh. Mobile: +8801728168861; E-mail: rakib_rezaul@blri.gov.bd

Received: 07 June 2016/Accepted: 22 June 2016/ Published: 30 June 2016

\begin{abstract}
The research was conducted to determine the approximate fat in milk for good quality dahi production and to inform dahi manufacturers' about the acceptable level of milk fat to be used and also their economic benefit. Quality assessment tests were conducted on four different types of dahi prepared by adding different percentage of milk fat such as 3.5\% (A), 4.0\% (B), 4.5\% (C) and 5.0\% (D) respectively. All the samples were analyzed for organoleptic, chemical and microbiological qualities. The scores for smell and taste, body and texture, color and appearance, and total scores for four types of dahi samples showed significant differences at various levels $(\mathrm{p}<0.01$ to $\mathrm{p}<0.05)$. It was found that scores for all the organoleptic parameters of sample $\mathrm{C}$ were the highest among the samples, whereas sample A obtained the lowest scores. Smell and taste, body and texture, total score, TS content, water content, fat content and coliform count were differed significantly $(\mathrm{P}<0.01)$. Color and appearance, protein content and \% acidity also showed significant differences $(\mathrm{P}<0.05)$, though $\mathrm{CHO}$ content, ash content and $\mathrm{pH}$ value showed insignificant differences. It could be concluded that sample $\mathrm{C}$ (containing $4.5 \%$ milk fat) was the best in terms of physical, chemical and microbiological qualities.
\end{abstract}

Keywords: dahi; milk fat; quality

\begin{abstract}
1. Introduction
Milk is an ideal and nature's almost perfect food. Together with milk, fermented milk products are occupying a greater portion of daily food menu of a modern civilized nation, certainly due to their great food values and palatability. Dahi is the popular and oldest fermented milk product for human being. It is generally considered as a safer product and its unique flavor appeals to so many that consideration is being given by nutritionists to incorporate inexpensive sources of nutrients to make it an almost complete food. It is a coagulated milk product produced by the activities of bacteria most common of which are Streptococcus thermophilus, Streptococcus lactis, Lactobacillus bulgaricus and Lactobacillus acidophilus.

Fermentation in milk consist essentially the gradual conversion of lactose into lactic acids by lactose fermentating organisms. The lactose molecule is enzymatically broken down by the enzyme lactase to glucose and galactose on its pathway (glycolytic pathway) towards lactic acid. Each of the simpler sugars is further acted upon by several routes of lactic acid and there can be several forms acid end products (Jenness and Patton, 1959). However, a portion of the acid combines with the calcium of casein to form calcium lactate, thus setting free the casein and coagulating it when its iso-electic point (pH 4.7) is reached (Rangappa and Achaya, 1971).
\end{abstract}


The nutrient content of dahi generally resembles with the milk from which it is made, although variations arise with differences in the type and strain of microorganisms, fermentation and storage conditions, and the addition of optional Ingredients such a non-fat milk solids (Dairy Industries International, 1991). Generally whole milk dahi contains $5-8 \%$ fat, 3.2-3.4\% protein, $4.6-5.2 \%$ lactose and $0.70-0.75 \%$ ash. Fermentation of milk by specific micro flora accompanying to technological modification and using some additives induces changes in taste, texture, visual appearance, color, flavor and the nutritive properties of the milk and produces a wide variety of food (Oberman and Libudzisz, 1998). Fermentation also imparts high therapeutic value to the fermented milk products (Adachi, 1992; Yamamoto et al., 1994).

There are different types of dahi are available in the market such as; sweet dahi, sour dahi and flavored dahi. At the same time nutritional benefit of dahi is very high. Moreover, due to the presence of probiotic bacteria, dahi have a lot of therapeutic values. In Bangladesh, milk production is very low, so less milk are available for preparation of this fermented product. Composition and quality of milk influences the quality of dahi. The aim of this research was to determine the appropriate level of fat in milk for good quality dahi production and also to study the costing of the manufactured dahi.

\section{Materials and Methods}

The experiment was carried out at the Dairy Technology and Microbiology Laboratories of the Department of Dairy Science, Bangladesh Agricultural University, Mymensingh. Whole milk was collected from the Bangladesh Agricultural University Dairy Farm, after milking in the morning, which was packed by poly bag. Suggestions were given to the milker's to maintain all hygienic measures like cleaning of udder and utensils etc. Milk was analyzed just after taking to the laboratory for getting idea about the initial quality of milk used in the experiment. After that, milk fat percentage of collected milk samples was tested and determined. Then milk was poured in a beaker and cream was separated from milk through an assembled cream separator. After cream separation the remaining whole milk was poured into four different beakers having less than 0.5 liter milk in each and calculated amount of milk fat or skim was added to the milk to get milk which contained milk fat about 5.0\%. 4.5\%, 4.0\%, and 3.5\% by using the Pearson Square method or Rectangle method for milk fat standardization. Finally additional whole milk was poured into the standardized sample to reach the total sample around 0.5 liters.

Milk was then heated to boiling temperature until reduced up to $20 \%$ of the volume of milk. At the time of boiling, sugar was added to the milk at the rate of $12 \%$. During heating milk was stirred thoroughly with the help of stirrer. After desired heating milk pan was taken out from the heater and allowed to cool down $40-45^{\circ} \mathrm{C}$. Then in a $500 \mathrm{ml}$ beaker $400 \mathrm{ml}$ heated milk was taken and starter culture was added to the milk at the rate of $2 \%$. Starter culture was dissolved properly by stirring it and then milk was poured in several pre-boiled water washed plastic cups of about $25 \mathrm{ml}$ size and kept undisturbed at an incubation temperature of $37^{\circ} \mathrm{C}$ until complete coagulation of the samples. After complete coagulation, the dahi samples were taken out from the incubator and were stored in a refrigerator at about $4^{\circ} \mathrm{C}$ until tested. So, four different types of dahi were prepared namely: $\mathrm{A}=$ Dahi containing 3.5\% milk fat, $\mathrm{B}=$ Dahi containing $4.0 \%$ milk fat, $\mathrm{C}=$ Dahi containing $4.5 \%$ milk fat, $\mathrm{D}=$ Dahi containing $5.0 \%$ milk fat.

All the dahi samples were judged by a team of experienced judges for organoleptic evaluation using a 100-point scale. Organoleptic parameters such as smell and taste (50), color and appearance (20), body and texture (30) were assessed separately, as their scores were added to a total score of 100. The grading scores were excellent (91-100), good (81-90), fair $(71-80)$ and poor $(<70)$. Acidity was determined by titrating with N/10 sodium hydroxide solution using the procedure of Aggarwala and Sharma (1961). The $\mathrm{pH}$ was measured with the help of a pH meter-215 (Ciba Coming Diagnostics Ltd., Sundhury, Suffolk, England Co 106xD). Fat content was determined by the Babcock method following the procedure described by Aggarwala and Sharma (1961). Crude protein content was determined by the Kjeldahl procedure (AOAC, 2003). Dry matter (DM) content was determined by oven drying method according to AOAC (2003). Ash content of dahi samples were determined by the incineration method according to AOAC (2003). Carbohydrate content was determined by deduction of the aggregate of all other constituents from 100. Standard Plate Count (colony forming unit per gram or cfu/g) and Coliform count (cfu/g) were done according to the method described by American Public Health Association (1998).

Data were statistically analyzed by using Analysis of variance (ANOVA) was carried out for means obtained for different parameters by Completely Randomized Design (CRD) with SPSS statistical package. Least significant difference (LSD) values were also determined to rank the samples. The experiment was replicated three times. Samples were analyzed in duplicate. 
3. Results and Discussion

\subsection{Initial quality of fresh milk}

Adulteration of milk by adding water decreases its specific gravity. In this experiment the average specific gravity of milk samples was within the normal range, which indicates that the quality of milk collected from BAU Dairy Farm was not adulterated and the initial quality of milk was acceptable. Generally the specific gravity of fresh milk is within the range of 1.031 to 1.035 having an average value of 1.032 (Eckles et al., 1951). Average acidity of collected milk samples were around 0.14 to 0.15 . Similarly standard acidity of milk ranges from 0.10 to 0.20 percent and the average value being 0.15 percent (Eckles et al. 1951). Moreover, the average fat content of collected milk samples were within the range of $40-50 \mathrm{~g} / \mathrm{kg}$ in each trial milks which is similar to the normal milk. To prepare different types of dahi, milk was standardized with different levels of milk fat.

The protein content of whole milk obtained in the study was within the normal range which was $32 \mathrm{to} 35 \mathrm{~g} / \mathrm{kg}$. Similar results previously reported that the protein content of cow's whole milk was 32.2 to 38.0 per cent respectively (Jenness and Patton, 1959). Nevertheless, average total solids content of collected milk samples were 120 to $130 \mathrm{~g} / \mathrm{kg}$ respectively. This result was in close agreement with Akter (2004), who reported that the total solids content of whole milk ranges from 12.8 to $13.50 \%$.

\subsection{Quality of dahi prepared by different levels of milk fat}

Smell and taste of different types of dahi samples are shown in Table 1. Statistical analysis showed that there were significant differences $(\mathrm{p}<0.01)$ within the smell and taste score of different types of dahi samples. Average highest score was seen in sample C (46.33 \pm 0.58$)$ followed by sample A $(42.19 \pm 1.26)$, B $(43.80 \pm 0.69)$ and D (43.91 \pm 0.47$)$. This result indicates that smell and taste score increased gradually with increased level of fat in milk up to $4.5 \%$ level and thereafter value declines (i.e, in sample D, containing 5.0\% fat in milk). Judges prefer dahi which was prepared from milk containing $4.5 \%$ milk fat. In addition, Alimoradi et al. (2013) reported that there was a positive effect of fat on smell and taste score of good quality dahi.

There were significant differences $(\mathrm{p}<0.01)$ in respect to body and texture scores of different types of Dahi. The body and texture score was highest in the sample $\mathrm{C}$, and the lowest in the samples A. This result indicates that fat level in milk improves body and texture of dahi samples. In this connection Altaf (2007) mentioned that increased fat level improved the body and consistency of dahi. In this experiment it was observed that dahi prepared from milk having $4.5 \%$ milk fat gave good body and texture. However, fat percent more than 4.5 in milk make the texture of the dahi more elastic type which panelist does not like.

Color and appearance score of this experimental sample was about 16.18 $\pm 0.95,17.22 \pm 0.57,18.15 \pm 0.71$ and $17.47 \pm 0.50$ for A, B, C and D type sample respectively (Table 1). Statistical analysis showed that there were significant differences $(\mathrm{p}<0.05)$ within this parameter of different dahi samples. Score was highest in $C$ type sample and lowest in A type sample. This result indicates that fat level in milk improves color and consistency of dahi samples. In addition, Pette and Lalkema (1991) reported that if the total solids content of milk sample is low then the texture of dahi will be low.

The overall scores of various types of dahi (Table 1) were determined on the basis of average of the scores recorded for different sensory attributes by using score curd for judging by a panel of expert judges. Statistical analysis showed that significant different was found in respect of overall score of different dahi samples. Dahi containing 4.5\% milk fat showed highest in the total score. In contrast, dahi containing 3.5\% milk fat showed the lowest value. The result of the present experiment agreed with those of Altaf (2007) and Bozanic et al. (2002).

Statistical analysis showed that total solid content and water content in different types of dahi samples (Table 2) differ significantly $(\mathrm{P}<0.01)$. Total solids content of sample D (containing 5.0\% milk fat) was higher than other samples. However, the highest water content was found in samples A because sample A contains lower amount of milk fat. The average range of different dahi samples was $260-280 \mathrm{~g} / \mathrm{kg}$. Sarker et al. (2000) reported that average total solids content of dahi collected from different district of west Bengal was within the range of 295.0 to $523.0 \mathrm{~g} / \mathrm{kg}$ with an average value of $402.7 \mathrm{~g} / \mathrm{kg}$. In addition, Ghosh and Rajorhia (1987) observed that total solids content of dahi varied from 269.2 to $430.4 \mathrm{~g} / \mathrm{kg}$ with an average value of $246.6 \mathrm{~g} / \mathrm{kg}$. Total solids content of dahi from this experiment was more or less similar to the findings of above two authors. The variation in total solids content of dahi could be attributed due to use of different amount of milk fat. This result showed that when milk fat content of dahi increase, total solids content in dahi will also increase. 
Table 1. Organoleptic parameters of Dahi prepared from different levels of milk fat content.

\begin{tabular}{lllllll}
\hline \multirow{2}{*}{ Parameters } & \multicolumn{4}{c}{ Treatment } & LSD & $\begin{array}{l}\text { Level of } \\
\text { value } \\
\text { sig. }\end{array}$ \\
\cline { 2 - 7 } & $\mathbf{A}$ & $\mathbf{B}$ & $\mathbf{C}$ & $\mathbf{D}$ & 0.880 & $* *$ \\
Smell and Taste (50) & $42.19^{\mathrm{c}} \pm 1.26$ & $43.80^{\mathrm{b}} \pm 0.69$ & $46.33^{\mathrm{a}} \pm 0.58$ & $43.91^{\mathrm{b}} \pm 0.47$ & 0.640 & $* *$ \\
Body and texture (30) & $24.81^{\mathrm{b}} \pm 0.20$ & $25.76^{\mathrm{b}} \pm 0.60$ & $27.71^{\mathrm{a}} \pm 0.96$ & $25.58^{\mathrm{b}} \pm 0.24$ & 0.762 & $*$ \\
Color and appearance (20) & $16.18^{\mathrm{b}} \pm 0.95$ & $17.22^{\mathrm{ab}} \pm 0.57$ & $18.15^{\mathrm{a}} \pm 0.71$ & $17.47^{\mathrm{ab}} \pm 0.50$ & 0.762 & $* 2.952$ \\
Total score (100) & $83.18^{\mathrm{c}} \pm 1.71$ & $86.78^{\mathrm{b}} \pm 0.55$ & $92.19^{\mathrm{a}} \pm 1.05$ & $86.96^{\mathrm{b}} \pm 0.99$ & 1.252 & $* *$ \\
\hline
\end{tabular}

A, Dahi containing 3.5\% milk fat; B, Dahi containing 4.0\% milk fat; C, Dahi containing 4.5\% milk fat; D, Dahi containing $5.0 \%$ milk fat; Means with different superscripts in the same row differed significantly; $*=$ Significant at $5 \%$ level $(\mathrm{p}<0.05) ; * *=$ Significant at $1 \%$ level $(\mathrm{p}<0.01)$

Table 2. Chemical parameters of Dahi prepared from different levels of milk fat content.

\begin{tabular}{|c|c|c|c|c|c|c|}
\hline \multirow{2}{*}{ Parameters } & \multicolumn{4}{|c|}{ Treatment } & \multirow{2}{*}{$\begin{array}{l}\text { LSD } \\
\text { value }\end{array}$} & \multirow{2}{*}{$\begin{array}{l}\text { Level } \\
\text { of sig. }\end{array}$} \\
\hline & $\mathbf{A}$ & B & $\mathbf{C}$ & D & & \\
\hline Total solids $(\mathrm{g} / \mathrm{kg})$ & $258.57^{\mathrm{d}} \pm 2.91$ & $264.13^{c} \pm 2.64$ & $269.88^{\mathrm{b}} \pm 2.71$ & $275.61^{\mathrm{a}} \pm 2.79$ & 3.006 & $* *$ \\
\hline Water $(\mathrm{g} / \mathrm{kg})$ & $741.43^{\mathrm{a}} \pm 2.91$ & $735.87^{\mathrm{b}} \pm 2.64$ & $730.12^{c} \pm 2.71$ & $724.39^{\mathrm{d}} \pm 2.79$ & 3.006 & $* *$ \\
\hline Fat $(\mathrm{g} / \mathrm{kg})$ & $39.03^{\mathrm{d}} \pm 0.058$ & $44.61^{\mathrm{c}} \pm 0.023$ & $50.13^{\mathrm{b}} \pm 0.115$ & $55.80^{\mathrm{a}} \pm 0.000$ & 0.069 & $* *$ \\
\hline Protein $(\mathrm{g} / \mathrm{kg})$ & $35.57^{\mathrm{b}} \pm 0.234$ & $35.81^{\mathrm{ab}} \pm 0.186$ & $35.98^{\mathrm{a}} \pm 0.072$ & $36.10^{\mathrm{a}} \pm 0.006$ & 0.168 & $*$ \\
\hline $\mathrm{CHO}(\mathrm{g} / \mathrm{kg})$ & $176.85 \pm 2.426$ & $176.63 \pm 2.326$ & $176.63 \pm 2.570$ & $176.60 \pm 2.627$ & 2.707 & NS \\
\hline $\operatorname{Ash}(g / k g)$ & $7.12 \pm 0.275$ & $7.17 \pm 0.151$ & $7.14 \pm 0.164$ & $7.12 \pm 0.161$ & 0.212 & NS \\
\hline Acidity (\%) & $0.71^{\mathrm{a}} \pm 0.010$ & $0.71^{\mathrm{a}} \pm 0.012$ & $0.70^{\mathrm{ab}} \pm 0.006$ & $0.69^{\mathrm{b}} \pm 0.010$ & 0.011 & $*$ \\
\hline $\mathrm{pH}$ & $4.50 \pm 0.100$ & $4.47 \pm 0.115$ & $4.62 \pm 0.029$ & $4.63 \pm 0.029$ & 0.084 & NS \\
\hline
\end{tabular}

A, Dahi containing 3.5\% milk fat; B, Dahi containing 4.0\% milk fat; C, Dahi containing 4.5\% milk fat; D, Dahi containing $5.0 \%$ milk fat; Means with different superscripts in the same row differed significantly; $*=$ Significant at $5 \%$ level $(\mathrm{p}<0.05) ; * *=$ Significant at $1 \%$ level $(\mathrm{p}<0.01) ; \mathrm{NS}=$ Non Significant

Table 3. Microbiological parameters of Dahi prepared from different levels of milk fat content.

\begin{tabular}{|c|c|c|c|c|c|c|}
\hline \multirow{2}{*}{ Parameters } & \multicolumn{4}{|c|}{ Treatment } & \multirow{2}{*}{ LSD value } & \multirow{2}{*}{$\begin{array}{l}\text { Level of } \\
\text { sig. }\end{array}$} \\
\hline & $\mathbf{A}$ & B & $\mathrm{C}$ & D & & \\
\hline $\begin{array}{l}\text { Total viable count } \\
(\mathrm{CFU} / \mathrm{ml})\end{array}$ & $76 \times 10^{5 a} \pm 3.5 \times 10^{5}$ & $74 \times 10^{5 \mathrm{ab}} \pm 4 \times 10^{5}$ & $68 \times 10^{5 b} \pm 3 \times 10^{5}$ & $67 \times 10^{5 b} \pm 3.6 \times 10^{5}$ & 386887.765 & $* *$ \\
\hline $\begin{array}{l}\text { Coliform count } \\
(\mathrm{CFU} / \mathrm{ml})\end{array}$ & $6.67^{\mathrm{a}} \pm 0.577$ & $6.67^{\mathrm{a}} \pm 2.309$ & $3.33^{\mathrm{b}} \pm 0.577$ & $3.33^{\mathrm{b}} \pm 0.577$ & 1.367711 & $*$ \\
\hline
\end{tabular}

A, Dahi containing 3.5\% milk fat; B, Dahi containing 4.0\% milk fat; C, Dahi containing 4.5\% milk fat; D, Dahi containing $5.0 \%$ milk fat; Means with different superscripts in the same row differed significantly; $*=$ Significant at $5 \%$ level $(\mathrm{p}<0.05) ; * *=$ Significant at $1 \%$ level $(\mathrm{p}<0.01)$; CFU=Colony Forming Unit

Table 4. Cost analysis of Dahi prepared from different levels of milk fat content.

\begin{tabular}{|c|c|c|c|c|}
\hline \multirow{2}{*}{ Items of expenditure } & \multicolumn{4}{|c|}{ Cost (Tk/Kg dahi) } \\
\hline & $\mathbf{A}$ & B & $\mathbf{C}$ & D \\
\hline Whole milk & 50 & 52.5 & 55 & 57.5 \\
\hline Container & 5 & 5 & 5 & 5 \\
\hline Fuel and electricity & 5 & 5 & 5 & 5 \\
\hline Starter culture & 1 & 1 & 1 & 1 \\
\hline Depreciation & 4 & 4 & 4 & 4 \\
\hline Sugar & 5.76 & 5.76 & 5.76 & 5.76 \\
\hline Total $(\mathrm{Tk} / \mathrm{kg})$ & 70.76 & 73.26 & 75.76 & 78.26 \\
\hline
\end{tabular}

A, Dahi containing 3.5\% milk fat; B, Dahi containing $4.0 \%$ milk fat; C, Dahi containing $4.5 \%$ milk fat; D, Dahi containing $5.0 \%$ milk fat 
Differences among the fat contents of different Dahi samples (Table 2) were significant $(p<0.01)$. Fat content of sample D was higher than that of other samples. The fat content of all Dahi samples were within the range of $39-56 \mathrm{~g} / \mathrm{kg}$, which is typical for sweet Dahi in Bangladesh (Mustafa, 1997). The fat content of Dahi of this experiment were also agreed with the findings of Ghosh and Rajorhia (1987) who observed that on an average fat content of Dahi was $48.33 \mathrm{~g} / \mathrm{kg}$.

Statistical analysis showed that protein contents (Table 2) of Dahi samples were differed significantly $(\mathrm{p}<0.05)$. Maximum protein content was found in sample C and D. On the other hand, lowest protein content was observed in sample A. The protein content of all Dahi samples ranged from $35-37 \mathrm{~g} / \mathrm{kg}$. The results of this study were slightly lower than those of Rahman (1998) who found that protein content of normal Dahi was around $38.9 \mathrm{~g} / \mathrm{kg}$. The protein content of Dahi used in this study was in agreement with Desai et al. (1994) who reported that the protein percentages of fresh milk Dahi were within the range of 37 to $43 \mathrm{~g} / \mathrm{kg}$. It was mentioned that when milk fat content in dahi increase, protein content will also be increase. However, the carbohydrate and the ash content of different Dahi samples (Table 2) were not differ significantly. The highest carbohydrate per cent was observed in sample A and the lowest value was recorded in sample D.

There was no significant difference among the samples for $\mathrm{pH}$ value (Table 2). Comparatively higher $\mathrm{pH}$ value was observed in sample D and the lower value was recorded in sample B. The range of $\mathrm{pH}$ value in different dahi samples was 4.50-4.65. The results of present findings agree with the work of Mustafa, (1997) who found that $\mathrm{pH}$ of dahi were 4.85. From another experiment, in case of cow milk dahi the result agreed with the findings of Rahman (1998). But the acidity content of different dahi samples showed significant differences $(\mathrm{p}<0.05)$. The range of acidity per cent in different dahi samples was $0.69-0.71$. The results of acidity of dahi samples agree with the findings of Sarker et al., (2000) who found that the titratable acidity of dahi was within the range of 0.36 to 1.17 . In this experiment acidity percent of dahi samples also agrees with the work of Desai et al., (1994) who found that the plain yogurt had titratable acidity of $0.78 \%$.

The total viable count per $\mathrm{ml}$ of dahi samples are presented in Table 3. It was observed that there were significant $(\mathrm{P}<0.05)$ differences among the dahi samples. The highest total viable count $/ \mathrm{ml}$ was recorded for sample A which indicates that it contains more favorable condition for growth of microbes and lowest value was recorded for sample D. It indicates that when milk fat increase, standard plate count will low.

The average coliform count per $\mathrm{ml}$ of Dahi samples A, B, C and D were $6.67 \pm 0.577,6.67 \pm 2.309,3.33 \pm 0.577$ and $3.33 \pm 0.577$ per $\mathrm{ml}$ respectively (Table 3 ). It was observed that there were significant $(\mathrm{p}<0.01)$ differences among the Dahi samples. The highest coliform count (coloni forming unit/g) was observed in sample A and the lowest was recorded in sample C and D. However, coliform count was within the standard value in every sample.

Cost analysis of different types of dahi prepared in the laboratory was presented in Table 4.The cost of per kilograms of dahi were @ Tk 70.76, 73.26, 75.76 and 78.26 for samples A, B, C and D respectively. The cost of whole milk varies with fat content in milk. The price of whole milk was assumed on the basis of milk fat content. For each dahi samples preparation $12 \%$ refined cane sugar was added and the price of refined cane sugarwas@ Tk 48/kg.

\section{Conclusions}

The experiment was conducted to check the organoleptic, chemical and microbiological qualities of dahi samples contained different levels of milk fat such as 3.5\%, 4.0\%, 4.5\% and 5.0\% milk fat. The comparative cost analysis was also done. Considering the results of all parameters (organoleptic, chemical and microbiological) it is obvious that there were wide variation in quality of different dahi samples. Though there score variation in different samples, but it can be supported that dahi which was prepared by adding $4.5 \%$ milk fat was best among the samples because this amount milk fat got higher scores in taste and smell, body and texture, color and consistency and it is also economically feasible.

\section{Conflict of interest}

None to declare.

\section{References}

Adachi S, 1992. Lactic acid bacteria and tumor control in lactic acid bacteria in health and disease. Elsevier Applied Science, pp. 233-261.

Akter S, 2004. Qualitative characteristic of dahi prepared from reconstituted milk. MS Thesis, Department of Dairy Science, Bangladesh Agricultural University, Mymensingh. 
Aggarwala AC and Sharma, 1961. A Laboratory manual of milk Inspection. $4^{\text {th }}$ edition Asia Publishing House, Bombay, Calcutta, New Delhi, India.

Alimoradi AH, SAY Adakani, HM Khosravi, Daneshim and A Shirzadi 2013. Using of Sesame oil as Fat Substitute in yoghurt. World of Science Journal, pp. 208-212.

Altaf, 2007. Preparation of dahi from cow milk with the addition of different levels of coconut milk. M.S. thesis, Dept. of Dairy Science, Bangladesh Agricultural University, Mymensingh.

American Public Health Association, 1998. Standard Methods for Examination of Dairy Products $20^{\text {th }}$ edn. Washington. D. C.

Association of Official Agricultural Chemists (AOAC), 2003. Official Methods of Analysis. 10 ${ }^{\text {th }}$ Edition. Washington D.C.

Bozanic R, I Rogelj and L Tratnik, 2002. Fermentation and storage of probiotic yoghurt from goat's milk. Mljekarstvo, 52: 93-111.

Dairy Industries International, 1991. Claims about the healthy properties of live yogurt abound clear penny reports on the latest investigations separating first from function. pp. 19-21.

Desai SR, VA Toro and SV Joshi, 1994. Utilization of different fruits in the manufacture of yogurt. Indian Journal Dairy Science, 47: 870-874.

Eckles CH, WB Combs and M Macy, 1951. In a book of, Milk and Milk products. $4^{\text {th }}$ edition. Mc Grow-mill book Book Company. New York, Toronto-London p.48.

Ghosh J and GS Rojorhia, 1987. Chemical microbiological and sensory properties of with misti dahi in Calcutta. Asian Journal of Dairy Science, 6:11-16.

Jenness R and S Patton, 1959. Principles of Dairy chemistry. John Wiley and Sons, Inc. London. pp. 97-98.

Mustafa MMH, 1997. A study on the preparation of fruit dahi (yoghurt). M. S. Thesis Department of Dairy Science, Bangladesh Agricultural University, Mymensingh.

Oberman H and Z Libudzisz, 1998. Physiological activity of Str. diacetilactis and Lb. cazci strains in continuous culture system. Acta Alimentaria polorica. Microbiology of Fermented Foods. Brain JB (editor). Wood Blackic Academic and Professional, Madras. pp. 308-350.

Pette JW and H Lalkema, 1991. Yoghurt III. Acid production and aroma formation in yoghurt. Netherland. Milk Dairy Journal, 4: 261-273.

Rahman M, 1998. A comparative study on cows' and buffaloes' milk and their shelf-life at room and refrigeration temperature. M.S. Thesis, Department of Dairy Science, Bangladesh Agricultural University, Mymensingh.

Rangappa SK and KT Achaya, 1971. Indian Dairy Products. $2^{\text {nd }}$ edition. Asia Publishing house, Bombay. pp. 119-124.

Sarker SP, JM Dave and SS Sannabhadti, 2000. A note on the effect of thermization of misti dahi on the acid productions count. Indian Journal of Dairy Science, 45: 131-134.

Yamamoto N, A Akino and T Takano, 1994. Antihypertensive effects of different kinds of fermented milk in spontaneously hypertensive rats. Biosciences, Biotechnology and Biochemistry, 58:776-778. 